\title{
Attitudes toward Civil Human Rights among Italian Students of Sociology: The Effects of Religion and Theology
}

\author{
Leslie J. Francis $^{1}$ (D), Olga Breskaya ${ }^{2, *(D)}$ and Ursula McKenna ${ }^{3}(\mathbb{D}$ \\ 1 Centre for Educational Development, Appraisal and Research (CEDAR), The University of Warwick, \\ Coventry CV4 7AL, UK; Leslie.Francis@warwick.ac.uk \\ 2 Department of Philosophy, University of Padova, 35122 Padova, Italy \\ 3 Department of Education Studies, The University of Warwick, Coventry CV4 7AL, UK; \\ U.McKenna@warwick.ac.uk \\ * Correspondence: olga.breskaya@unipd.it
}

Received: 26 October 2020; Accepted: 25 November 2020; Published: 1 December 2020

\begin{abstract}
Connecting with and building on the research tradition established by The International Empirical Research Programmes in Religion and Human Rights, this study explores the power of two measures shaped within empirical theology (the Theology of Religions Index that distinguishes seven ways in which religions may be viewed and the New Indices of God Images that distinguishes between the God of Grace and the God of Law) to predict individual differences in attitude toward civil human rights among students of sociology under the age of thirty who had lived in Italy all their lives, after taking into account the effect of baptismal status (Catholic or not Catholic) and frequency of mass attendance. Data provided by 1046 participants demonstrated that more positive attitudes toward civil human rights are associated with being male, with not being baptised Catholic, with not attending mass, and with the God of Grace, but not with the God of Law. Five of the positions identified within the framework of the theology of religions are significant predictors of attitude toward civil human rights: the most positive attitude is associated with atheism and the least positive attitude is associated with exclusivism.
\end{abstract}

Keywords: empirical theology; psychology of religion; human rights; Italy; Catholic Church

\section{Introduction}

The complex patterning of relations between human rights and religion has been richly illuminated by independent yet interrelated empirical studies conducted within the two sequential programmes, The International Empirical Research Programme in Religion and Human Rights 1.0, and The International Empirical Research Programme in Religion and Human Rights 2.0, as illustrated by the following monographs and edited collections: van der Ven (2010); van der Ven and Ziebertz (2012, 2013); Ziebertz and Ballin (2016); Ziebertz and Črpić (2015); Ziebertz and Sterkens (2018); Sterkens and Ziebertz (2018); Ziebertz and Zaccaria (2019); and Ziebertz (2020a) Three important conclusions emerging from these independent yet interrelated studies are that the connections between human rights and religion may vary according to the specific human rights under discussion, according to the specific conceptualisations and operationalisations of religion employed in empirical enquiry, and according to the populations studied.

During the span of the two international research programmes on religion and human rights, the range of national contexts studied included: Belarus (Breskaya and Döhnert 2018), Chile (Silva and Manzi 2018; Manzi and Silva 2019), Croatia (Miloš and Novak 2018), England and Wales (Francis and Robbins 2013, 2016; Francis et al. 2016, 2018a, 2018b, 2019b, 2020), Georgia (Unser et al. 2020), 
Germany (Ziebertz and Reindl 2012, 2013; Gennerich and Ziebertz 2016; Ziebertz et al. 2018; Ziebertz 2019, 2020b), Indonesia (Sterkens and Hadiwitanto 2016), Italy (Zaccaria et al. 2018a, 2018b, 2019; Anthony et al. 2020), Lithuania (Ališauskienè and Maslauskaitè 2019), Moldova (Unser et al. 2020), Nigeria (Adimekwe and Ziebertz 2018a, 2018b; Fumbo et al. 2019, 2020), Norway (Botvar 2013, 2018; Botvar and Sjöborg 2018; Botvar et al. 2019), Palestine (Webb et al. 2012; Webb and Asa'd 2018, 2019; Webb et al. 2020), Poland (Botvar et al. 2019), Romania (Rogobete and Reisz 2018; Rogobete and Vitelar 2020), South Africa (Dreyer and Aziz 2020), Spain (Oviedo and Canteras 2018), Sweden (Sjöborg 2012; Botvar and Sjöborg 2018), Tamil Nadu (Anthony 2013; Anthony and Sterkens 2018, 2019), Tanzania (van der Tuin and Fumbo 2012; Fumbo and Sterkens 2018; Fumbo and Ziebertz 2018; Fumbo et al. 2019, 2020), and Turkey (Ok and Eren 2013; Ok et al. 2020).

In comparative studies, van der Ven $(2013,2016,2020)$ drew on data from Belgium, England and Wales, Germany, The Netherlands, Norway, and Sweden; Unser et al. (2016) drew on data from Germany, India, Indonesia, Kenya, Nigeria, and Sweden; Unser et al. (2018) drew on data from Belarus, Croatia, Georgia, Germany, India, Italy, Lithuania, Nigeria, Norway, Poland, Romania, Switzerland, and Tanzania; and Breskaya et al. (2019) drew on data from Belarus, Norway, Romania, and Sweden.

Within the family of studies conducted within the two international research programmes on religion and human rights, different sets of studies have focused on civil human rights (Ziebertz and Sterkens 2018), political and judicial rights (Sterkens and Ziebertz 2018), rights to life (Ziebertz and Zaccaria 2019), and socioeconomic rights (Ziebertz 2020a). Within the family of studies, religion has been operationalised by a range of instruments reflecting different perspectives taken by the empirical sociology of religion, the empirical psychology of religion, and empirical theology.

\subsection{Research Agenda}

Against this broad contextualisation within the empirical research initiated by The International Empirical Research Programme in Religion and Human Rights 1.0 and The International Empirical Research Programme in Religion and Human Rights 2.0, the aim of the present study is to augment the rich tapestry of data emerging from these independent yet interrelated studies by specifying a specific cultural context, by focusing on a specific area of human rights, and by considering the power of two constructs shaped within empirical theology to predict individual differences in attitude toward human rights, after taking into account fundamental religious measures of affiliation and practice. The cultural context is identified as Italian students of sociology; the specific aspect of human rights is identified as civil human rights; and the two constructs shaped within empirical theology concern the theologies of religions and God images.

\subsection{Civil Human Rights}

Civil human rights and political human rights are generally discussed together, following the International Convention on Civil and Political Rights (see Conte and Burchill 2009, pp. 319-35; Nickel 2007, pp. 213-31). Considered together, civil and political rights are those rights under which individuals can live in freedom and liberty and which allow them to participate in the civil and political life of society without discrimination or repression. According to Conte and Burchill (2009, p. 3) the discussion of civil and political rights implies a distinction between two different, but related sets of rights.

While civil rights are those rights which are calculated to protect an individual's physical and mental integrity, to ensure that they are not the victims of discrimination, and to preserve their right to a fair trial, political rights are those which ensure that individuals are able to participate fully in civil society. Such rights include rights of democratic participation, such as the right to vote and to participate in the public life of the State, freedom of expression and assembly, and freedom of thought, conscience and religion. 
Francis et al. (2018a, pp. 2-3) argue that civil and political rights, considered together, as covered by the International Covenant on Civil and Political Rights, include three main areas. The first area concerns individual liberties and security of the person and is guaranteed by Article 9 . The right to privacy (Article 17), freedom of movement (Article 12), freedom of religion (Article 18) and expression (Article 19), rights of detainees to be treated with humanity and dignity (Article 10), and freedom from torture (Article 7) constitute a broader framework for the protection of individuals in this area. The second area concerns procedural fairness in law. It guarantees the right to recognition as a person before the law (Article 16) and a right to a fair trial (Article 14). The third area concerns political freedoms that entitle individuals to participate in peaceful assemblies (Article 21) and associations with others (Article 22) and the right of citizens to political participation (Article 25).

\subsection{Assessing Attitudes toward Civil Human Rights}

Drawing on the pool of items available within The International Empirical Research Programme on Religion and Human Rights 1.0, Ok and Eren (2013) constructed a 12-item scale designed to assess attitudes toward civil human rights. These 12 items covered six conceptual areas that they defined as freedom of press, rights to privacy, protection from torture, freedom of assembly, rights to protest, and judicial rights. These six conceptual areas cohered to generate a good level of internal consistency reliability $(\alpha=0.80)$ among a sample of 422 students from Turkey between the ages of 13 and 18 years. These six conceptual areas were operationalised in the following way.

Freedom of press was assessed by two items:

- TV journalists with radical ideas have a civil right to employment;

- Newspaper columnists should be free to express radical convictions.

Rights to privacy were assessed by two items:

- Police searches of private homes without a search warrant are prohibited;

- The police are only allowed to inspect people's cars under strict judicial conditions.

Protection from torture was assessed by two items:

- Inflicting severe physical suffering on potential terrorists is prohibited;

- Imposing inhuman mental treatment on people accused of mass murder is forbidden.

Freedom of assembly was assessed by two items:

- A cabinet minister should allow his striking officials to meet in a ministerial building;

- Minority groups should be free to use the town hall to hold protest meetings.

Rights to protest were assessed by two items:

- The police should not use force against political demonstrations;

- The government should not pass a law forbidding all forms of public protest.

Judicial rights were assessed by two items:

- Guaranteeing terrorists access to a lawyer is necessary to protect their individual rights;

- A mass murderer should be informed of his/her rights to keep silent before the court.

The 12-item scale of attitudes toward civil human rights developed by Ok and Eren (2013) was employed in a replication study by Francis and Robbins (2016), with minor revision to improve English language fluency. In this replication study, the scale generated a good level of internal consistency reliability $(\alpha=0.78)$ among a sample of 1058 students from England and Wales between the ages of 14 and 18 years who self-assigned as Christian, Muslim, or religiously unaffiliated.

In a subsequent study, still drawing on data available within the International Empirical Research Programme on Religion and Human Rights 1.0, Francis et al. (2018a) reduced the 12-item scale 
proposed by Ok and Eren (2013) and replicated by Francis and Robbins (2016) by the two items concerned with freedom of the press. Among their sample of 1058 students from England and Wales between the ages of 14 and 18 years who self-identified as Christian, Muslim, or religiously unaffiliated, this ten-item scale generated a good level of internal consistency reliability $(\alpha=0.76)$.

Drawing on a pool of 16 items available within The International Empirical Research Programme on Religion and Human Rights 2.0 which they identify as relevant to civil human rights, Zaccaria et al. (2018a) employ factor analysis on data provided by 1078 Italian Catholic students between the ages of 15 and 21 years to identify ten items that, under Oblim rotation with Kaiser Normalisation, generate four subscales: a three-item subscale concerned with women's rights $(\alpha=0.81)$, a three-item subscale concerned with gay and sexual rights $(\alpha=0.74)$, a two-item subscale concerned with freedom of assembly $(\alpha=0.46)$, and a two-item subscale concerned with freedom of religion $(\alpha=0.42)$. They do not report data on the total scale.

\subsection{Exploring Connections with Religion}

Ok and Eren (2013) drew on data provided by 422 students between the ages of 13 and 18 years from two secondary schools in a rural Turkish city, Sivas, to test the connection between their 12-item scale of attitudes towards civil human rights and three measures of religion: a three-item scale of religious salience (My religion or worldview has great influence on my daily life), a six-item scale of religious openness (Religions or worldviews are all equal; they are all directed to authentic life), and a six-item scale of religious stress (I feel that I should not question my religion, but I sometimes do anyway). Bivariate correlations demonstrated that positive attitudes toward civil human rights were associated with high religious stress, high religious openness, and low religious saliency. Multiple regression analysis that considered all three religious variables as well as sex, age and political preference, and identified religious openness to be the core (and only) predictor of more positive attitudes toward civil human rights.

Francis and Robbins (2016) drew on data provided by 1058 students from England and Wales between the ages of 14 and 18 years who self-assigned as Christian, Muslim, or religiously unaffiliated, to test the connection between their 12-item scale of attitude toward civil human rights and three measures of religion: self-assigned religious affiliation (employing Christian and Muslim as two dummy variables against no religious affiliation), a four-item scale of religious saliency (My religion or worldview is important to me), and a six-item scale of interreligious openness (There is no difference between religions or worldviews; they all stem from a longing for truth). Bivariate correlations demonstrated that positive attitudes toward civil human rights were associated with high religious saliency, high interreligious openness, and with being Muslim. Multiple regression analysis that considered all three religious variables as well as sex, age, political preference, and the Eysenckian dimensions of personality (extraversion, neuroticism, and psychoticism; Eysenck and Eysenck 1991), confirmed that both religious saliency and interreligious openness predicted more positive attitudes toward civil human rights. However, within the environment of multiple regression, the effect of being Muslim moved from being significantly positive to significantly negative. Within this environment there was also a significant negative path from being Christian. In other words, the cultural identification as either Christian or Muslim without religious saliency is associated with lower endorsement of civil human rights.

Francis et al. (2018a) drew on the data provided by 1058 students from England and Wales to test whether their three-item scale of mystical experience added any further predictive power in respect of attitudes toward civil human rights after taking into account the predictor variables already included by Francis and Robbins (2016). The data demonstrated that this additional measure accounted for no additional variance in attitude toward civil human rights. 


\subsection{Theology of Religions}

The first insight brought to the present project from the domain of empirical theology concerns the field of enquiry known as the theology of religions. This field of enquiry is concerned with the way in which theologians working within a religious tradition interpret and evaluate the divergent truth-claims and the divergent views of salvation that are asserted or implied by different religious traditions. The issue is not simply to do with how one religion (say Christianity) views another religion (say Islam) but also how one strand within the same religion (say Roman Catholicism) views another strand within the same religion (say Anglicanism).

Reviewing the broader theoretical literature on the range of positions within the theology of religions, Astley and Francis (2016) distinguish among six positions that they define in the following ways.

- Exclusivism is the traditional view that only one religious belief-system is true. Theological exclusivism (or "particularism") holds that religious truth is "primarily restricted to a particular religion" (Netland 2007, p. 229).

- Inclusivism is the view that one religion includes the key truths that are found within the other religious belief-systems; it, therefore, holds that this one system is pre-eminent and normative, but acknowledges that other faiths contain some truths. This has also been designated the fulfilment model (Peter Phan, cited in Durka 2012, p. 18).

- Pluralism privileges no one religious tradition, maintaining rather that all—or most—religious claims are on a par with respect to truth, especially when the religions speak of different, but non-conflicting, human conceptions of some ultimately ineffable reality (e.g., Hick 1995, chps. 1, 3; Hick 1997, pp. 612-13). Its exponents often argue that it is the same truth that is being manifested and recounted in different ways in these different religious traditions. This has also been called the multireligious model (Ziebertz 2012, p. 167).

- The interreligious perspective expresses the view that real, complete truth in religion comes only through exploration of and dialogue between the different religions. The position is equivalent to Phan's mutuality model (Durka 2012, p. 19).

- Atheism implies the view that the central claims of no religion are true (with the exception of some species of nontheistic Buddhism).

- Agnosticism is the view that we do not, perhaps even cannot, know which religious claims are true.

The first four of these positions were operationalised in a series of four short scales of three or four items each and used in a series of studies by Ziebertz (1993, 1995, 1996, 2003, 2005, 2007, 2012). Ziebertz's scales can be characterised by one example item from each.

- Exclusivism: My religion contains the one true light of redemption.

- Inclusivism: Compared to my religion, other religions contain only part of the truth.

- Multireligiosity: All religions are equally valuable; they are different paths to the same salvation.

- Interreligiosity: The real truth can only be discovered in the communication between religions.

Reviewing the Ziebertz model, Astley and Francis (2016) suggested four issues that deserved further investigation. First, on conceptual grounds, they suggested that the four positions identified by the Ziebertz model did not adequately allow for non-religious positions, arguing for the addition of two further positions shaped to recognise atheism and agnosticism. Second, on empirical grounds, they wished to challenge the value of attempting to measure complex constructs, such as exclusivism, inclusivism, multireligiosity and interreligiosity, by scales of only three or four items. They argued that well-designed single item measures may be just as effective, although less effective than longer scales designed to access more fully developed constructs. Third, they questioned the sophistication of adolescent theological literacy to distinguish clearly between such nuanced statements offered independently. They argued that a well-designed multiple-choice question may force greater clarity in 
the adolescent mind. Fourth, they suggested that the view of pluralism needed to be captured through two formulations that they styled pluralism A and pluralism B, with one of these formulations more sophisticated than the other.

Flowing from their critique of the Ziebertz model, Astley and Francis (2016) proposed a multiple-choice question inviting participants to choose the one of the seven statements that comes closest to their own belief. Astley and Francis' Theology of Religions Index (AFTRI) proposed the following items.

- Exclusivism: Only one religion is really true and all others are totally false.

- Inclusivism: Only one religion is really true but at least one other is partly true.

- Pluralism A: All religions are equally true.

- Pluralism B: All religions express the same truth in different ways.

- Interreligious perspective: Real truth comes from listening to all religions.

- Atheism: All religions are totally false.

- Agnosticism: I do not know what to believe about religions.

The Astley-Francis Theology of Religions Index has been deployed in a series of analyses, including studies by Francis and McKenna (2017a, 2017b), Francis et al. (2019a, 2019c), and Breskaya and Giordan (forthcoming).

\subsection{God Images}

The second insight brought to the present project from the domain of empirical theology concerns the field of enquiry known as God images. Empirical research concerned with conceptualising and measuring God images has its roots within the empirical psychology of religion (Hegy 2007). This field is best explored through consideration of the range of instruments to which it has given rise (see, for example, Hill and Hood 1999). Among these instruments, the measure proposed by Benson and Spilka (1973) has gained some prominence through consistent use (wholly or in part) by researchers over more than four decades, including studies by Spilka et al. (1975), Chartier and Goehner (1976), Jolley and Taulbee (1986), Kirkpatrick and Shaver (1990, 1992), Brokaw and Edwards (1994), Kirkpatrick (1998), Rowatt and Kirkpatrick (2002), Webb et al. (2005), Granqvist et al. (2007), Reinert and Edwards (2009), Krentzman et al. (2011), Soenens et al. (2012), Gebauer and Maio (2012), Meisenhelder et al. (2013), and Vonk and Pitzen (2016).

In their original conceptualisation and operationalisation, Benson and Spilka (1973) developed a ten-item semantic differential grid with a seven-point space between the opposing poles (see Osgood et al. 1957). From this grid, they proposed two separate five-item scales: the "oving God" index (rejecting-accepting, loving-hating, damning-saving, unforgiving-forgiving, and approving-disapproving) and the "controlling God" index (demanding-not demanding, freeing-restricting, controlling-non-controlling, strict-lenient, and permissive-rigid). In their original study, Benson and Spilka (1973) reported a significant negative correlation between the two measures $(r=-0.30, p<0.01)$, indicating clear overlap between them. Subsequent studies reported higher correlations between the two measures, including: $r=0.43$ by Webb et al. (2005); $r=0.59$ by Reinert and Edwards (2009); and $r=0.63$ by Vonk and Pitzen (2016). Clearly, Benson and Spilka (1973) distinction between the loving God and the controlling God had not identified clear orthogonal factors.

Continuing to work with the ten-item semantic differential grid proposed by Benson and Spilka (1973), Francis et al. (2006) tested its factor structure, removed two of the ten items, and re-interpreted the new eight-item measure as defining unidimensional semantic space relating to God images ranging from positive affect to negative affect. In this semantic space, positive affect was defined by the descriptors: saving, accepting, not-demanding, loving, freeing, forgiving, approving, and lenient. Negative affect was defined by the descriptors: damning, rejecting, demanding, hating, restricting, unforgiving, disapproving, and strict. 
In a subsequent study, Francis et al. (forthcoming) suggested that the reconceptualization of the semantic space as distinguishing between God images ranging from positive affect to negative affect raises issues for both psychological and theological investigation. From a psychological perspective, the notion of locating positive affect and negative affect as opposite poles of a continuum runs counter to the well-established psychological notion, rooted in Bradburn (1969) model of balanced affect, that negative affect and positive affect operate as independent systems. According to this understanding, it should be possible to measure the two systems independently and not to see one as the mirror image of the other. This basic psychological insight suggests that the bipolar model of the semantic differential grid may not be the best way to measure God images that reflect positive affect and negative affect. As a consequence, Francis et al. (forthcoming) proposed taking key descriptors from the original scales proposed by Benson and Spilka (1973) and presenting them in the classic Likert format.

From a theological perspective, the descriptors that have clustered to define God images to the negative affect pole of the scale may confuse a range of categories. Theologically, a God who is hating and rejecting may be very different from a God who is demanding and strict. Alongside the insights generated from a psychology of religion approach, additional insight may be generated from an empirical theology approach to help to reconceptualise the measurement of God images. As a consequence, Francis et al. (forthcoming) turned attention to the two potentially contrasting images of God that may be characterised as God of Grace and God of Law. In so doing, Francis et al. (forthcoming) changed the language in which God images are discussed from psychological discourse, as evidence by the notions of "loving God" and "controlling God" proposed by Benson and Spilka (1973), to theological discourse. They argued that a discernible and consistent theological difference may be sustained differentiating between the image of God of Law and the image of God of Grace, and that this difference can be traced through the Old Testament and through the New Testament.

Francis et al. (forthcoming) argued that this distinction between the contrasting images of God of Grace and God of Law emerges in both the Old Testament and the New Testament through theological reflection on significant crises experienced in the historical trajectory of faith in God. From the perspective of the Old Testament, the crisis of faith was brought about by the experience of exile when God appeared to have reneged on promises made to God's chosen people. From the perspective of the New Testament, the crisis of faith was brought about by the experience of crucifixion when God appeared to have reneged on promises made to God's chosen people through the Messiah.

Underpinning the image of God of Law is the world view which is essentially anxious, and which believes that God's good intentions in creation stand in danger of being subverted by human sinfulness. Law is all that stands between chaos and the maintenance of life in peace and enjoyment. In its fullest expression, it is a central theme of Deuteronomy, which itself is the manifesto of a group with a particular understanding of God in a postexilic setting. They believe that the Exile was in fact a terrible reminder of what happens when human agency is set against divine will, and law is disregarded. For the Deuteronomistic (D) writers, God is hence both loving and jealous (Mills 1998). God is loving in so far as God has gifted a chosen people with a land and their freedom, and the means and structures that will enable a society to flourish (all of which is tied up with the theological idea of Covenant). God is jealous and even angry and wrathful when the story of freedom is disregarded; when the gratefulness is ceremonial rather than sincere; when the law is flouted, and when other gods who offer easier conditions for living are entertained. This is set out in inescapable clarity at Deuteronomy 30: $15-20$.

Underpinning the image of God of Grace is the world view which is essentially optimistic and which believes that human corruption and sin will be overcome by God's grace. While the D theology is essentially political and concentrates on the political and historical act of liberation as the setting for the establishment of the nation, Priestly (P) theology, which holds the optimistic view, is based on the concept of creation, and the sure belief that God has promised that life on the whole earth will 
persist, sin notwithstanding, as set out at Genesis 9: 7-17. It is a sacramental theology which sees God's purposes in the interconnectedness of creation, rather than the persistence of a state.

By the time of Jesus, these two views have been fused in an institutional religio-political way. It could be argued that Paul seeks to disentangle them, while highlighting the dangers of such institutionalisation. Following the D tradition, Paul affirms the political and liberating act which is evidenced in the election and establishment of Israel, as a theological entity. However, he disputes the contemporary interpretation of how admission is gained to "Israel", and also the soteriological consequence of equating "Israel" with a religio-political system that appears to make salvation contingent upon the keeping of the law (Sanders 1977). Hence, his writings emphasise the initiative of God, acting in a graceful and loving way towards humankind, rather than the attempt by humans to maintain good relations with God by keeping the law. Though not an exact parallel with the Old Testament distinction discussed above, the basic fault line is discernible between an anxious approach to a God who demands adherence to the law as a condition of salvation (law), and a loving and gracious God whose personal intervention in human history is evidence of a hopeful investment in humankind, despite itself (grace).

Moreover, Francis et al. (forthcoming) argued that these two theological systems should not be correlated with one another. In their foundation analysis, this principle was confirmed by the unrotated component analysis matrix for principal component analysis that recorded a clear two-factor structure from this instrument: the New Indices of God Images. It is these two orthogonal measures assessing God of Grace and God of Law proposed by the New Indices of God Images (NIGI), as developed by Francis et al. (forthcoming), that are employed in the present study.

\subsection{Research Question}

Against this background, the present study was designed to explore, among Italian university students of sociology, the connection between attitudes toward civil human rights and both religious variables and theological variables. In this context, religious variables are conceptualised as baptismal status (baptised Catholic) and as frequency of mass attendance; and theological variables are conceptualised as theology of religions and as God images reflecting the God of Grace and the God of Law.

\section{Method}

\subsection{Procedure}

Students participating in the sociology programme of Padua University, Italy (academic years 2016-2017 and 2017-2018) were invited to complete a short survey exploring the views of Italians today on life, religion, and human rights. Participation was voluntary. Participants were guaranteed anonymity and confidentiality. The research was conducted within the ethical guidelines of the University of Padua. The survey was completed by 1302 participants.

\subsection{Measures}

The following measures were drawn from the survey for the purposes of the present analysis. Sex was coded: male (1) and female (2).

Age groups were coded: under 20 (1), 20-29 (2), 30-39 (3), 40-49 (4), 50-59 (5), 60-69 (6), 70-79 (7), 80 and over (8).

Baptismal status was coded: baptised Catholic (2), no (1).

Mass attendance was coded: never (1), sometimes (2), monthly (3), and weekly (4).

Residence in Italy was coded: all my life (4), at least ten years (3), less than ten years (2), I do not live there (1).

God images were assessed by the New Indices of God Images (NIGI) proposed by Francis et al. (forthcoming). This instrument contains three items reflecting the God of Grace, and three items 
reflecting the God of Law, derived from the original conceptualisation proposed by Benson and Spilka (1973). These items are posed so that they can be addressed both by those who believe in God and by those who do not believe in God. Each item is assessed on a five-point scale: agree strongly (5), agree (4), not certain (3), disagree (2), and disagree strongly (1).

Theology of religions was assessed by a modified form of the Astley-Francis Theology of Religions Index (AFTRI: Astley and Francis 2016). This index distinguishes among seven positions: exclusivism, inclusivism, pluralism A, pluralism B, interreligious perspective, atheism, and agnosticism. Participants responded to each of the seven statements in their revised form on a five-point scale: agree strongly (5), agree (4), not certain (3), disagree (2), and disagree strongly (1).

Civil human rights were assessed by the 12-item scale employed by Francis and Robbins (2016). Each item was assessed on a five-point scale: agree strongly (5), agree (4), not certain (3), disagree (2), and disagree strongly (1).

\subsection{Participants}

The present analysis was based on the participants under the age of thirty who had lived in Italy all their lives and fully completed all the relevant measures within the survey. Of the 1302 participants, 1046 matched these criteria. Of these 1046 participants, 310 were male (30\%) and 736 were female $(70 \%) ; 283$ were under the age of twenty $(27 \%)$ and 763 were in their twenties $(73 \%)$. The majority were baptised Catholics (92\%); 10\% attended mass weekly, and a further $10 \%$ attended mass at least once a month, $43 \%$ never attended mass, and $37 \%$ attended less frequently than once a month.

\subsection{Analysis}

The data were analysed by SPSS using the frequency, reliability, correlation, factor, and regression routines.

\section{Results and Discussion}

The first step in data analysis explored the scale properties of the 12-item Scale of Attitude toward Civil Rights in terms of the alpha coefficient (Cronbach 1951), the correlations between the individual items and the sum of the other 11 items, and the item endorsement as the sum of the agree and agree strongly responses. The data presented in Table 1 indicate that the scale functioned with satisfactory internal consistency reliability ( $\alpha=0.81$ ), each of the 12 items covaried with the sum of the remaining 11 items ( $r$ ranging from 0.29 to 0.62 ), and the individual items showed a good range of endorsements (from $31 \%$ to $79 \%$ ).

The data presented in Table 1 also allow an assessment to be made of the overall level of support expressed for the six main themes within civil human rights incorporated within the 12-item scale. In terms of freedom of the press, $49 \%$ agreed that journalists with radical ideas should have the right to work, and $35 \%$ agreed that journalists should be allowed to express radical views. In terms of rights to privacy, $70 \%$ agreed that the police should not be allowed to search private homes without a warrant, and $66 \%$ agreed that police should not be allowed to inspect private cars without a warrant. In terms of protection from torture, $43 \%$ agreed that political terrorists should not be subjected to physical suffering, and $40 \%$ agreed that people accused of mass murder should not be subjected to psychological suffering. In terms of freedom of assembly, 77\% agreed that minority groups should be allowed to use public buildings for protests, and $45 \%$ agreed that politicians should allow their staff to hold protest meetings in their building. In terms of rights of protest, $79 \%$ agreed that the state should not forbid public protests, and $60 \%$ agreed that the police should not be allowed to use force against political demonstrators. In terms of judicial rights, $45 \%$ agreed that mass murderers should be made aware of their rights to keep silent before the court, and 31\% agreed that terrorists should be guaranteed access to a lawyer to protect their rights. 
Table 1. Scale of attitude toward civil rights.

\begin{tabular}{|c|c|c|}
\hline & $r$ & Yes \% \\
\hline \multicolumn{3}{|l|}{ Freedom of press } \\
\hline Journalists with radical ideas should have the right to work & 0.40 & 49 \\
\hline Journalists should be allowed to express radical views & 0.29 & 35 \\
\hline \multicolumn{3}{|l|}{ Rights to privacy } \\
\hline Police should not be allowed to search private homes without a warrant & 0.40 & 70 \\
\hline Police should not be allowed to inspect private cars without a warrant & 0.41 & 66 \\
\hline \multicolumn{3}{|l|}{ Protection from torture } \\
\hline Political terrorists should not be subjected to physical suffering & 0.62 & 43 \\
\hline People accused of mass murder should not be subjected to psychological suffering & 0.59 & 40 \\
\hline \multicolumn{3}{|l|}{ Freedom of assembly } \\
\hline Minority groups should be allowed to use public buildings for protests & 0.54 & 77 \\
\hline Politicians should allow their staff to hold protest meetings in their building & 0.38 & 45 \\
\hline \multicolumn{3}{|l|}{ Rights to protest } \\
\hline The state should not forbid public protests & 0.40 & 79 \\
\hline Police should not be allowed to use force against political demonstrators & 0.44 & 60 \\
\hline \multicolumn{3}{|l|}{ Judicial rights } \\
\hline Mass murderers should be made aware of their right to keep silent before the court & 0.54 & 45 \\
\hline Terrorists should be guaranteed access to a lawyer to protect their rights & 0.57 & 31 \\
\hline Alpha & 0.81 & \\
\hline
\end{tabular}

Note: $r=$ correlation between item and sum of the other items; yes $\%=$ sum of the agree and agree strongly responses.

The second step in data analysis explored the scale properties of the six items of the New Indices of God Images Francis et al. (forthcoming), in terms of the factor structure, the alpha coefficients (Cronbach 1951) of the two scales of the God of Grace and the God of Law, the correlations between the individual items and the sum of the other items within each of these scales, and the item endorsement as the sum of the agree and agree strongly responses. The data presented in Table 2 indicate that confirmatory factor analysis (principal components with varimax rotation constrained to a two factor solution) recovered the clear distinction between the three God of Grace descriptors as factor one (accounting for $58.1 \%$ of variance) and the three God of Law descriptors as factor two (accounting for ( $26.1 \%$ of variance).

Table 2. New Indices of God images (NIGI).

\begin{tabular}{lcccc}
\hline & \multicolumn{2}{c}{ Factors } & & Yes \\
\hline God of Grace & $\mathbf{1}$ & $\mathbf{2}$ & $\boldsymbol{r}$ & $\mathbf{\%}$ \\
$\quad$ Loving & & & & \\
Forgiving & 0.94 & & 0.88 & 47 \\
Accepting & 0.95 & & 0.92 & 46 \\
God of Law & 0.94 & & 0.90 & 48 \\
Strict & & 0.84 & 0.69 & 13 \\
Disapproving & & 0.90 & 0.75 & 7 \\
Demanding & & 0.83 & 0.69 & 15 \\
Alpha & 0.95 & 0.84 & & \\
\hline
\end{tabular}

Note: factor loading below 0.3 are suppressed; $r=$ correlation between the individual item and the other three items in the scale; yes = sum of agree and agree strongly responses.

The three items of the Index of the God of Grace (loving, forgiving, and accepting) achieved a high level of internal consistency reliability $(\alpha=0.95)$ and each was endorsed by nearly half of the participants: forgiving (46\%), loving (47\%), and accepting (48\%). The three items of the Index of the God of Law (strict, disapproving, and demanding) achieved a satisfactory level of internal consistency 
reliability $(\alpha=0.84)$ and each was endorsed by a minority of the participants: disapproving $(7 \%)$, strict $(13 \%)$, and demanding $(15 \%)$.

The third step in data analysis explored the level of endorsement of the seven items derived from the Astley-Francis Theology of Religions Index (Astley and Francis 2016). This index distinguished between seven positions: exclusivism, inclusivism, pluralism A, pluralism B, interreligious perspective, atheism, and agnosticism. The data presented in Table 3 indicate that the two expressions of pluralism received the highest levels of endorsement: $55 \%$ of the participants endorsed the view that all religions are equally true (pluralism A) and 58\% endorsed the view that all religions express the same truth in different ways (pluralism B). The expression of the interreligious perspective was endorsed by $33 \%$ of the participants who agreed that religious truth comes from listening to all religions. The expression of exclusivism was endorsed by $3 \%$ of the participants who agreed that only one religion is really true and all others are totally false. The expression of inclusivism was endorsed by $5 \%$ of the participants who agreed that only one religion is really true but at least one other is partly true. The expression of atheism was endorsed by $8 \%$ of the participants who agreed that all religions are totally false. The expression of agnosticism was endorsed by $27 \%$ of the participants who agreed that they did not know what to believe about religion.

Table 3. Theologies of religion.

\begin{tabular}{lc}
\hline & Yes \% \\
\hline Only one religion is really true and all others are totally false & 3 \\
Only one religion is really true but at least one other is partly true & 5 \\
All religions are equally true & 55 \\
All religions express the same truth in different ways & 58 \\
Real truth comes from listening to all religions & 33 \\
All religions are totally false & 8 \\
I do not know what to believe about religions & 27 \\
\hline
\end{tabular}

Note: yes \% = combined agree strongly and agree responses.

The fourth step in data analysis explored the bivariate correlations (using the Pearson product moment correlation coefficient) between the dependent variable (attitudes toward civil human rights) and each of the independent variables: two personal factors (sex and age), two religious factors (being baptised Catholic and frequency of mass attendance), two God images (God of Grace and God of Law), and seven positions identified within the theology of religions (exclusivism, inclusivism, pluralism A, pluralism B, interreligious perspective, atheism, and agnosticism). The data presented in the first column of Table $4(r)$ indicate that one of the two personal factors is a significant predictor: more positive attitudes toward civil human rights are associated with being male. Both of the religious factors are significant predictors: more positive attitudes toward civil human rights are associated with not being baptised Catholic and with not attending Mass. Both of the God image factors are significant predictors: more positive attitudes toward civil human rights are associated with the God of Grace $(p<0.05)$ and not with the God of Law $(p<0.001)$. Five of the positions identified within the framework of the theology of religions are significant predictors: more positive attitudes toward civil human rights are associated with atheism $(p<0.01)$; less positive attitudes toward civil human rights are associated with exclusivism $(p<0.001)$, inclusivism $(p<0.001)$, interreligious perspective $(p<0.05)$, and agnosticism $(p<0.001)$.

The fifth step in data analysis explored the cumulative effects of the four groups of independent variables within a sequence of four regression models (using stepwise fixed entry linear multiple regression). The independent variables were entered in four steps. Model one explored the effects of personal factors. Model two explored the effects of religious factors after personal factors had been taken into account. Model three explored the effects of God images after personal and religious factors had been taken into account. Model four explored the effects of the Theology of Religions after 
personal, religious, and God image factors had been taken into account. The increase in $\mathrm{R}^{2}$ reported in Table 4 indicates that each step added significant predictive power to the model.

Table 4. Regression models.

\begin{tabular}{|c|c|c|c|c|c|c|c|}
\hline \multirow[b]{2}{*}{ Personal factors } & \multicolumn{2}{|l|}{$r$} & $\begin{array}{c}\text { Model } 1 \\
\beta\end{array}$ & $\begin{array}{c}\text { Model } 2 \\
\beta\end{array}$ & $\begin{array}{c}\text { Model } 3 \\
\beta\end{array}$ & \multicolumn{2}{|c|}{$\underset{\beta}{\text { Model } 4}$} \\
\hline & & & & & & & \\
\hline Sex & -0.09 & $* *$ & $-0.08^{* *}$ & $-0.08^{* *}$ & $-0.09 * *$ & -0.07 & $*$ \\
\hline Age & 0.02 & & 0.01 & 0.00 & 0.00 & -0.01 & \\
\hline \multicolumn{8}{|l|}{ Religious factors } \\
\hline Catholic & -0.08 & $* *$ & & -0.06 & -0.05 & -0.06 & $*$ \\
\hline Mass attendance & -0.12 & $* * *$ & & $-0.11^{* * *}$ & $-0.11^{* *}$ & -0.10 & $* *$ \\
\hline \multicolumn{8}{|l|}{ God images } \\
\hline God of Law & -0.13 & $* * *$ & & & $-0.13 * *$ & -0.08 & $*$ \\
\hline God of Grace & 0.06 & $*$ & & & 0.05 & 0.06 & \\
\hline \multicolumn{8}{|l|}{ Theology of Religions } \\
\hline Exclusivism & -0.22 & $* * *$ & & & & -0.23 & $* * *$ \\
\hline Inclusivism & -0.15 & $* * *$ & & & & 0.03 & \\
\hline Pluralism A & -0.02 & & & & & -0.03 & \\
\hline Pluralism B & 0.02 & & & & & 0.03 & \\
\hline Interreligious & -0.06 & $*$ & & & & -0.04 & \\
\hline Atheism & 0.08 & $* *$ & & & & 0.08 & $*$ \\
\hline Agnosticism & -0.14 & $* * *$ & & & & -0.14 & $* * *$ \\
\hline $\mathrm{R}^{2}$ & & & 0.01 & 0.02 & 0.04 & 0.11 & \\
\hline$\Delta$ & & & $0.01 *$ & $0.02^{* * *}$ & $0.01^{* * *}$ & 0.07 & $* * *$ \\
\hline
\end{tabular}

Model 4 presented in Table 4 demonstrates the cumulative effect of each variable when all are considered within the model. These data indicate that among Italian students of sociology, the strongest predictor of individual differences in attitude toward civil human rights is the Index of Theology of Religions. The least positive attitude toward civil human rights is held by participants who hold an exclusivism position toward religion and by participants who hold an agnostic position toward religion. The most positive attitude toward civil human rights is held by participants who hold an atheism position toward religion. Within this cumulative model, a less positive attitude toward civil human rights is associated with being male, with being baptised Catholic, with frequent Mass attendance, and with endorsing the image of the God of Law.

\section{Conclusions}

For more than a decade, the two waves of The International Empirical Research Programme in Religion and Human Rights have been generating and publishing analyses of national and cross-national data on human rights. Drawing on empirical evidence, international scholars have explored the embeddedness of civil freedoms, human dignity, and equality into the cultural codes of national societies, and also identified the predictive power of individual religiosity, the role of religious institutions, and broader socio-political contexts vis-à-vis attitudes towards human rights (van der Ven 2010; van der Ven and Ziebertz 2012, 2013; Ziebertz 2020a). Within this context, our aim in this study was to explore among a sample of 1046 Italian University students of sociology the connection between attitudes toward civil human rights and both religious variables and theological variables. In this context, religious variables were conceptualised as baptismal status (baptised Catholic) and as frequency of mass attendance; and theological variables were conceptualised with the Theology of Religions Index and as God images reflecting the God of Grace and the God of Law. Three main conclusions emerge from these data. 
The first conclusion from these data concerns the insights into attitudes toward civil human rights generated by the 12-item scale on civil rights as proposed by Francis and Robbins (2016). The statements measuring the right to protest, freedom of assembly, and rights to privacy were endorsed by Italian sociology students more than other civil rights (agreement expressed from $70 \%$ to $79 \%$ ). Meanwhile, judicial right formulated as "Terrorists should be guaranteed access to a lawyer to protect their rights" and right to free press operationalized as "Journalists should be allowed to express radical views" were least favoured among them ( $31 \%$ and $35 \%$, respectively).

The second conclusion concerns the insights into the theological understanding of Italian University students of sociology generated by the two instruments proposed by empirical theology. The New Indices of God Images (NIGI; Francis et al. (forthcoming), comprising the Index of God of Grace and the Index of God of Law, showed that the former was more favoured by respondents in comparison with the latter. Around $40 \%$ difference in the perception of these two indices was observed for several statements supporting the semantic distance between these two images of God. Results on Astley-Francis Theology of Religions Index (AFTRI; Astley and Francis 2016) suggested that the pluralistic perspective is predominant among the Italian sample (58\%) followed by the interreligious (33\%) and the agnostic $(27 \%)$ positions. Similar results were recently obtained by an empirical study on Social Perception of Religious Freedom which implemented the AFTRI to explore its effect on the multidimensional concept of religious freedom for Italian University students (Breskaya and Giordan forthcoming). In that study, AFTRI was measured with a forced-choice question with seven possible answers. The results suggested that the pluralism position, which claims that all religions express the same truth in different ways, was prevailing in the sample of Italian youth, followed by the agnostic position and by the interreligious perspective.

The third conclusion is that both the NIGI and the AFTRI are significant predictors of individual differences in attitudes towards civil human rights. Endorsement of the image of the God of Law and endorsement of the exclusivism, agnosticism, and atheism positions were associated with less favourable attitudes towards civil human rights. In terms of religious variables, the fact of being baptised in the Catholic Church and frequent mass attendance were also negatively correlated with attitudes toward civil human rights. Meanwhile, the pluralistic perspective had no statistical effect on attitudes toward civil human rights. Similar empirical evidence was revealed in the study by Breskaya and Giordan (forthcoming). These authors argued that the absence of association between the concept of pluralism as a theological truth-claim and perception of religious freedom can be considered in the context of the privatization of religious lifestyles in Italy (Berzano 2019), while religious freedom is seen primarily as a societal value (Breskaya and Giordan 2019). Similar to the current study, the positions that are more antithetical to pluralism, such as exclusivism and atheism, are significant predictors of attitudes toward religious freedom.

Moreover, in Italy, the high degree of incorporation of religious codes into Italian culture and the high identification level of young people with Catholicism produced distinctive models of youth religious subculture (Giordan 2008), which according to Garelli (2014) can be seen as an exception from a wide-spread European model of believing without belonging. That specificity can be seen through the perception of religion by young people as a "common-sense religion, useful to provide a shared code of identification rather than ... a conscious and personal choice" (Giordan 2010, p. 356). Thus, pluralistic truth-claims being endorsed by respondents as a set of private religious perspectives appear to be more important as a common-sense statement; however, disconnected from socio-political claims of public life. This finding requires further analysis, adjusting its effect by religious and socio-political identities.

In terms of shaping future research within the field of religion and human rights, the present study has drawn attention to the importance of identifying and operationalising theological variables as well as religious variables. Both the strengths and the limitations of the present study are related to the specificities of the sample and of the instruments employed. The study drew on students participating in the sociology programme of Padua University. Future research needs to test these findings on other populations. This study employed a measure of the theology of religions developed by Astley and 
Francis (2016) and of God images developed by Francis et al. (forthcoming). Future research needs to explore other operationalisations of these constructs.

Author Contributions: The article was jointly conceived in dialogue between three authors. L.J.F. and U.M. took the lead in writing the sections: "Introduction" and "Method", while O.B. took the lead in writing the sections: "Results and discussion" and "Conclusion". All authors have read and agreed to the published version of the manuscript.

Funding: This research received no external funding.

Conflicts of Interest: The authors declare no conflict of interest.

\section{References}

Adimekwe, Modestus, and Hans-Georg Ziebertz. 2018a. Attitudes towards freedom of religion among Nigerian students. In Religion and Civil Human Rights in Empirical Perspective. Edited by Hans-Georg Ziebertz and Carl Sterkens. Cham: Springer, pp. 177-214. [CrossRef]

Adimekwe, Modestus, and Hans-Georg Ziebertz. 2018b. Predictors of judicial human rights' attitudes of adolescents in Nigeria. In Political and Judicial Rights through the Prism of Religious Belief. Edited by Carl Sterkens and Hans-Georg Ziebertz. Cham: Springer, pp. 217-54. [CrossRef]

Ališauskienè, Milda, and Aušra Maslauskaitè. 2019. Attitudes towards the right to life and the religiosity of young people in Lithuania. In Euthanasia, Death Penalty and Religion: The Right to Life and Its Limitations: International Empirical Research. Edited by Hans-Georg Ziebertz and Francesco Zaccaria. Cham: Springer, pp. 187-208. [CrossRef]

Anthony, Francis-Vincent. 2013. Public significance of religion with regard to socioeconomic rights in the multireligious context of Tamil Nadu, India. In Human Rights and the Impact of Religion. Edited by Johannes A. van der Ven and Hans-Georg Ziebertz. Leiden: Brill, pp. 205-44. [CrossRef]

Anthony, Francis-Vincent, and Carl Sterkens. 2018. Extending political rights to immigrants and refugees. In Political and Judicial Rights through the Prism of Religious Belief. Edited by Carl Sterkens and Hans-Georg Ziebertz. Cham: Springer, pp. 145-84. [CrossRef]

Anthony, Francis-Vincent, and Carl Sterkens. 2019. Religion and the right to (dispose of) life: A study of the attitude of Christian, Muslim and Hindu students in India concerning death penalty, euthanasia and abortion. In Euthanasia, Death Penalty and Religion: The Right to Life and Its Limitations: International Empirical Research. Edited by Hans-Georg Ziebertz and Francesco Zaccaria. Cham: Springer, pp. 13-64. [CrossRef]

Anthony, Francis-Vincent, Francesco Zaccaria, and Carl Sterkens. 2020. Impact of religion on socio-economic rights: An empirical study of Italian students' attitude. In International Empirical Studies on Religion and Socio-Economic Human Rights. Edited by Hans-Georg Ziebertz. Cham: Springer, pp. 63-100. [CrossRef]

Astley, Jeff, and Leslie J. Francis. 2016. Introducing the Astley-Francis Theology of Religions Index (AFTRI): Construct validity among 13- to 15-year-old students. Journal of Beliefs and Values 37: 29-39. [CrossRef]

Benson, Peter, and Bernard Spilka. 1973. God image as a function of self-esteem and locus of control. Journal for the Scientific Study of Religion 12: 297-10. [CrossRef]

Berzano, Luigi. 2019. The Fourth Secularization: Autonomy of Individual Lifestyles. London: Routledge. [CrossRef]

Botvar, Pål K. 2013. Religion and attitudes towards socioeconomic human rights: An empirical study of young adults in Norway. In Human Rights and the Impact of Religion. Edited by Johannes A. van der Ven and Hans-Georg Ziebertz. Leiden: Brill, pp. 245-63. [CrossRef]

Botvar, Pål K. 2018. Social capital and religion in the public sphere: Attitudes to visible forms of religion among Norwegian high-school students. In Religion and Civil Human Rights in Empirical Perspective. Edited by Hans-Georg Ziebertz and Carl Sterkens. Cham: Springer, pp. 141-56. [CrossRef]

Botvar, Pål K., and Anders Sjöborg. 2018. Social conflicts, religion and human rights support: A study of young Christians and Muslims in Scandinavia. In Political and Judicial Rights through the Prism of Religious Belief. Edited by Carl Sterkens and Hans-Georg Ziebertz. Cham: Springer, pp. 255-74. [CrossRef]

Botvar, Pål K., Claudia Sarti, Katarzyna Zielińska, and Marcin K. Zwierżdżyński. 2019. Religion and attitudes towards abortion and euthanasia among young people in Poland and Norway. In Euthanasia, Death Penalty and Religion: The Right to Life and Its Limitations: International Empirical Research. Edited by Hans-Georg Ziebertz and Francesco Zaccaria. Cham: Springer, pp. 243-70. [CrossRef] 
Bradburn, Norman M. 1969. The Structure of Psychological Well-Being. Chicago: Aldine. [CrossRef]

Breskaya, Olga, and Susanne Döhnert. 2018. Understanding human dignity: Theoretical groundings and empirical findings among the youth in Belarus. In Religion and Civil Human Rights in Empirical Perspective. Edited by Hans-Georg Ziebertz and Carl Sterkens. Cham: Springer, pp. 61-90. [CrossRef]

Breskaya, Olga, and Giuseppe Giordan. 2019. Measuring the social perception of religious freedom: A sociological perspective. Religions 10: 274. [CrossRef]

Breskaya, Olga, and Giuseppe Giordan. forthcoming. One, many or none: Religious truth-claims and social perception of religious freedom. In Religious Freedom: Social-Scientific Approaches, Annual Review of the Sociology of Religion. Edited by Olga Breskaya, Roger Finke and Giuseppe Giordan. Leiden: Brill.

Breskaya, Olga, Pål K. Botvar, Anders Sjöborg, and Silviu Rogobete. 2019. Religion, trust in institutions and attitudes towards abortion: A comparison of Lutheran and Orthodox countries. In Euthanasia, Death Penalty and Religion: The Right to Life and its Limitations: International Empirical Research. Edited by Hans-Georg Ziebertz and Francesco Zaccaria. Cham: Springer, pp. 271-99. [CrossRef]

Brokaw, Beth F., and Keith J. Edwards. 1994. The relationship of God image to level of object relations development. Journal of Psychology and Theology 22: 352-71. [CrossRef]

Chartier, Myron R., and Larry A. Goehner. 1976. A study of the relationship of parental-adolescent communication, self-esteem, and God image. Journal of Psychology and Theology 4: 227-32. [CrossRef]

Conte, Alex, and Richard Burchill. 2009. Defining Civil and Political Rights: The Jurisprudence of the United Nations Human Rights Committee. Farnham: Ashgate.

Cronbach, Lee J. 1951. Coefficient alpha and the internal structure of tests. Psychometrika 16: 297-334. [CrossRef]

Dreyer, Jaco S., and Garth Aziz. 2020. Religion and socio-economic rights among the youth of South Africa. In International Empirical Studies on Religion and Socio-Economic Human Rights. Edited by Hans-Georg Ziebertz. Cham: Springer, pp. 39-62. [CrossRef]

Durka, Gloria. 2012. Theology of religions: Through the looking glass of US Roman Catholicism. In Teaching Religion, Teaching Truth: Theoretical and Empirical Perspectives. Edited by Jeff Astley, Leslie J. Francis, Mandy Robbins and Mualla Selçuk. Bern: Peter Lang, pp. 11-29.

Eysenck, Hans J., and Sybil B. G. Eysenck. 1991. Manual of the Eysenck Personality Scales. London: Hodder and Stoughton. Francis, Leslie J., and Ursula McKenna. 2017a. Assessing attitude towards religious diversity among Muslim adolescents in the UK: The effect of religious and theological factors. Journal of Beliefs and Values 38: 328-40. [CrossRef]

Francis, Leslie J., and Ursula McKenna. 2017b. Muslim attitude toward freedom of religious clothing and symbols in schools within the UK: The effect of religious and theological factors. Religione e Società 32: 50-58.

Francis, Leslie J., and Mandy Robbins. 2013. Religion, personality and human rights: An empirical study among adolescents in England and Wales distinguishing between religious identity and textual authority among Christians and Muslims. In Human Rights and the Impact of Religion. Edited by Johannes A. van der Ven and Hans-Georg Ziebertz. Leiden: Brill, pp. 97-118. [CrossRef]

Francis, Leslie J., and Mandy Robbins. 2016. Attitudes toward human rights and religiosity among adolescents in England and Wales: Replicating and extending a study in Turkey. In Freedom of Religion in the Twenty-First Century: A Human Rights Perspective on the Relationship between Politics and Religion. Edited by Hans-Georg Ziebertz and Ernst H. Ballin. Leiden: Brill, pp. 105-29. [CrossRef]

Francis, Leslie J., Mandy Robbins, and Harry M. Gibson. 2006. A revised semantic differential scale distinguishing between negative and positive God images. Journal of Beliefs and Values 27: 237-40. [CrossRef]

Francis, Leslie J., Mandy Robbins, and Ursula McKenna. 2016. Women's socio-economic rights and religion among Christian, Islamic, and non-religiously affiliated students in England and Wales. Collected edition. In Freedom of Religion in the Twenty-First Century: A Human Rights Perspective on the Relationship between Politics and Religion. Edited by Hans-Georg Ziebertz and Ernst H. Ballin. Leiden: Brill, pp. 239-56. [CrossRef]

Francis, Leslie J., Ursula McKenna, and Mandy Robbins. 2018a. Attitude toward political rights and religious affiliation, experience, saliency and openness: An empirical enquiry among students in England and Wales. In Political and Judicial Rights through the Prism of Religious Belief. Edited by Carl Sterkens and Hans-Georg Ziebertz. Cham: Springer, pp. 1-21. [CrossRef] 
Francis, Leslie J., Andrew G. Village, Ursula McKenna, and Gemma Penny. 2018b. Freedom of religion and freedom of religious clothing and symbols in school: Exploring the impact of church schools in a religiously diverse society. In Religion and Civil Human Rights in Empirical Perspective. Edited by Hans-Georg Ziebertz and Carl Sterkens. Cham: Springer, pp. 157-75. [CrossRef]

Francis, Leslie J., Jeff Astley, and Ursula McKenna. 2019a. Science disproves the biblical account of creation: Exploring the predictors of perceived conflict between science and religion among 13- to 15-year-old students in the UK. British Journal of Religious Education 41: 188-201. [CrossRef]

Francis, Leslie J., Ursula McKenna, and Abdullah Sahin. 2019b. Religion, human rights and matters of life and death: Exploring attitude toward abortion and euthanasia among adolescents in England and Wales. In Euthanasia, Death Penalty and Religion: The Right to Life and its Limitations: International Empirical Research. Edited by Hans-Georg Ziebertz and Francesco Zaccaria. Cham: Springer, pp. 139-59. [CrossRef]

Francis, Leslie J., Gemma Penny, and Jeff Astley. 2019c. Christian identities, theologies of religion, and attitude towards religious diversity: A study among 13- to 15-year-old students across the UK. In Young People and the Diversity of (Non)Religious Identities in International Perspective. Boundaries of Religious Freedom: Regulating Religion in Diverse Societies. Edited by Elisabeth Arweck and Heather Shipley. Cham: Springer, pp. 87-107. [CrossRef]

Francis, Leslie J., Ursula McKenna, and Abdullah Sahin. 2020. Religion and socio-economic human rights: An empirical enquiry among adolescents in England and Wales. In International Empirical Studies on Religion and Socio-Economic Human Rights. Edited by Hans-Georg Ziebertz. Cham: Springer, pp. 169-91. [CrossRef]

Francis, Leslie J., John Holdsworth, and Ursula McKenna. forthcoming. Introducing the New Indices of God images (NIGI): Distinguishing between God of Grace and God of Law. under review.

Fumbo, Clement, and Carl Sterkens. 2018. Advancing civil human rights culture in Tanzania. In Religion and Civil Human Rights in Empirical Perspective. Edited by Hans-Georg Ziebertz and Carl Sterkens. Cham: Springer, pp. 215-29. [CrossRef]

Fumbo, Clement, and Hans-Georg Ziebertz. 2018. Judicial rights among youth in Tanzania. In Political and Judicial Rights through the Prism of Religious Belief. Edited by Carl Sterkens and Hans-Georg Ziebertz. Cham: Springer, pp. 185-216. [CrossRef]

Fumbo, Clement, Modestus Adimekwe, and Hans-Georg Ziebertz. 2019. Death penalty and the right to life: A comparative empirical study in Tanzania and Nigeria. In Euthanasia, Death Penalty and Religion: The Right to Life and Its Limitations: International Empirical Research. Edited by Hans-Georg Ziebertz and Francesco Zaccaria. Cham: Springer, pp. 209-42. [CrossRef]

Fumbo, Clement, Modestus Adimekwe, and Hans-Georg Ziebertz. 2020. Right to education in Tanzania and Nigeria: A comparative study. In International Empirical Studies on Religion and Socio-Economic Human Rights. Edited by Hans-Georg Ziebertz. Cham: Springer, pp. 193-234. [CrossRef]

Garelli, Franco. 2014. Religion Italian Style: Continuities and Changes in a Catholic Country. Burlington: Ashgate.

Gebauer, Jochen E., and Gregory R. Maio. 2012. The need to belong can motivate belief in God. Journal of Personality 80: 465-501. [CrossRef]

Gennerich, Carsten, and Hans-Georg Ziebertz. 2016. Human rights and value priorities. In Freedom of Religion in the Twenty-First Century: A Human Rights Perspective on the Relation between Politics and Religion. Edited by Hans-Georg Ziebertz and Ernst H. Ballin. Leiden: Brill, pp. 206-38. [CrossRef]

Giordan, Giuseppe. 2008. Giovani allo Specchio. Una Ricerca in Valle d'Aosta. Milano: FrancoAngeli.

Giordan, Giuseppe. 2010. Believers in progress: Youth and religion in Italy. In Annual Review of the Sociology of Religion. Edited by Giuseppe Giordan. Leiden: Brill, pp. 353-81. [CrossRef]

Granqvist, Pehr, Tord Ivarsson, Anders G. Broberg, and Berit Hagekull. 2007. Examining relations among attachment, religiosity, and new age spirituality using the adult attachment interview. Developmental Psychology 43: 590-601. [CrossRef]

Hegy, Pierre, ed. 2007. What do We Imagine God to Be? The Function of 'God Images' in Our Lives. Lewiston: Edwin Mellen Press.

Hick, John. 1995. The Rainbow of Faiths: Critical Dialogues on Religious Pluralism. London: SCM Press.

Hick, John. 1997. Religious pluralism. In A Companion to Philosophy of Religion. Edited by Philip L. Quinn and Charles Taliaferro. Malden and Oxford: Blackwell, pp. 607-14.

Hill, Peter C., and Ralph W. Hood, eds. 1999. Measures of Religiosity. Birmingham: Religious Education Press. 
Jolley, Jerry C., and Steven J. Taulbee. 1986. Assessing perceptions of self and God's comparison of prisoners and normals. Psychological Reports 59: 1139-46. [CrossRef]

Kirkpatrick, Lee A. 1998. God as a substitute attachment: A longitudinal study of attachment style and religious change in college students. Personality and Social Psychology Bulletin 24: 961-73. [CrossRef]

Kirkpatrick, Lee A., and Phillip R. Shaver. 1990. Attachment theory and religion: Childhood attachments, religious beliefs, and conversion. Journal for the Scientific Study of Religion 29: 315-34. [CrossRef]

Kirkpatrick, L. A., and Phillip R. Shaver. 1992. An attachment-theoretical approach to romantic love and religious belief. Personality and Social Psychology Bulletin 18: 226-75. [CrossRef]

Krentzman, Amy R., Elizabeth A. R. Robinson, Brian E. Perron, and James A. Cranford. 2011. Predictors of membership in Alcoholics Anonymous in a sample of successfully remitted alcoholics. Journal of Psychoactive Drugs 43: 20-26. [CrossRef]

Manzi, Jorge, and Joaquin Silva. 2019. The right to life among Chilean youth. In Euthanasia, Death Penalty and Religion: The Right to Life and Its Limitations: International Empirical Research. Edited by Hans-Georg Ziebertz and Francesco Zaccaria. Cham: Springer, pp. 105-38.

Meisenhelder, Janice B., Nancy J. Schaeffer, Jerry Younger, and Marisa Lauria. 2013. Faith and mental health in an oncology population. Journal of Religion and Health 52: 505-13. [CrossRef]

Mills, Mary. 1998. Images of God in the Old Testament. London: Cassell.

Miloš, Djokovic, and Krunoslav Novak. 2018. The role of value orientations and political preference on political and judicial human rights among the Croatian youth. In Political and Judicial Rights through the Prism of Religious Belief. Edited by Carl Sterkens and Hans-Georg Ziebertz. Cham: Springer, pp. 71-94. [CrossRef]

Netland, Harold A. 2007. Inclusivism and exclusivism. In The Routledge Companion to Philosophy of Religion. Edited by Chad Meister and Paul Copan. London: Routledge, pp. 226-36.

Nickel, James W. 2007. Making Sense of Human Rights, 2nd ed. Oxford: Blackwell Publishing.

Ok, Üzeyir, and Selim S. Eren. 2013. Attitudes towards human rights and religiosity: A case of Turkish adolescents. In Human Rights and the Impact of Religion. Edited by Johannes A. van der Ven and Hans-Georg Ziebertz. Leiden: Brill, pp. 145-65. [CrossRef]

Ok, Üzeyir, Ayse B. Goren, Sidika Akbulut, and Songul D. Getir. 2020. Do religious Muslims help the poor more than non-religious? In International Empirical Studies on Religion and Socio-Economic Human Rights. Edited by Hans-Georg Ziebertz. Cham: Springer, pp. 277-98. [CrossRef]

Osgood, Charles E., George J. Suci, and Percy H. Tannenbaum. 1957. The Measurement of Meaning. Urbana: University of Illinois Press.

Oviedo, Lluis, and Manuel Canteras. 2018. Religion and political rights in the Spanish context: Looking for developments. In Political and Judicial Rights through the Prism of Religious Belief. Edited by Carl Sterkens and Hans-Georg Ziebertz. Cham: Springer, pp. 23-44. [CrossRef]

Reinert, Duane F., and Carla E. Edwards. 2009. Attachment theory, childhood mistreatment, and religiosity. Psychology of Religion and Spirituality 1: 25-34. [CrossRef]

Rogobete, Silviu E., and Robert D. Reisz. 2018. Religion, political and judicial rights in post-communist, post-atheist spaces: An empirical analysis among youth in Romania. In Political and Judicial Rights through the Prism of Religious Belief. Edited by Carl Sterkens and Hans-Georg Ziebertz. Cham: Springer, pp. 95-122. [CrossRef]

Rogobete, Silviu E., and Ligia Vitelar. 2020. Religion and existential security: An empirical study of religion and socio-economic rights amongst high-school learners in post-atheist, post-totalitarian Romania. In International Empirical Studies on Religion and Socio-Economic Human Rights. Edited by Hans-Georg Ziebertz. Cham: Springer, pp. 101-28. [CrossRef]

Rowatt, Wade C., and Lee A. Kirkpatrick. 2002. Two dimensions of attachment to God and their relation to affect, religiosity, and personality constructs. Journal for the Scientific Study of Religion 41: 637-51. [CrossRef]

Sanders, Ed Parish. 1977. Paul and Palestinian Judaism. London: SCM Press.

Silva, Joaquin, and Jorge Manzi. 2018. The role of religion in society, and its relation to the attitudes towards human rights in Chile. In Religion and Civil Human Rights in Empirical Perspective. Edited by Hans-Georg Ziebertz and Carl Sterkens. Cham: Springer, pp. 121-40. [CrossRef]

Sjöborg, Anders. 2012. The impact of religion on freedom of religion and freedom of speech among young Swedes. In Tensions within and between Religions and Human Rights. Edited by Johannes A. van der Ven and Hans-Georg Ziebertz. Leiden: Brill, pp. 147-75. [CrossRef] 
Soenens, Bart, Bart Neyrinck, Maarten Vansteenkiste, Jessie Dezutter, Dirk Hutsebaut, and Bart Duriez. 2012. How do perceptions of God as autonomy supportive or controlling relate to individuals' social-cognitive processing of religious contents? The role of motives for religious behaviour. The International Journal for the Psychology of Religion 22: 10-30. [CrossRef]

Spilka, Bernard, Addison James, and Rosensohn Marguerite. 1975. Parents, self and God: A test of competing theories of individual-religion relationships. Review of Religious Research 16: 154-65. [CrossRef]

Sterkens, Carl, and Handi Hadiwitanto. 2016. Empirical models of the relationship between religion and state in Indonesia. In Freedom of Religion in the Twenty-First Century: A Human Rights Perspective on the Relation between Politics and Religion. Edited by Hans-Georg Ziebertz and Ernst H. Ballin. Leiden: Brill, pp. 162-206. [CrossRef]

Sterkens, Carl, and Hans-Georg Ziebertz, eds. 2018. Political and Judicial Rights through the Prism of Religious Belief. Cham: Springer. [CrossRef]

Unser, Alexander, Susanne Döhnert, and Hans-Georg Ziebertz. 2016. The influence of the socio-cultural environment and personality on attitudes towards civil human rights. In Freedom of Religion in the Twenty-First Century: A Human Rights Perspective on the Relation between Politics and Religion. Edited by Hans-Georg Ziebertz and Ernst H. Ballin. Leiden: Brill, pp. 130-61. [CrossRef]

Unser, Alexander, Susanne Döhnert, and Hans-Georg Ziebertz. 2018. Attitudes towards refugee rights in thirteen countries: A multi-level analysis of the impact and interaction of individual and socio-cultural predictors. In Political and Judicial Rights through the Prism of Religious Belief. Edited by Carl Sterkens and Hans-Georg Ziebertz. Cham: Springer, pp. 275-302. [CrossRef]

Unser, Alexander, Sophie Zviadadze, Susanne Döhnert, Marina Shupac, and Hans-Georg Ziebertz. 2020. Predictors of attitudes towards the right to work: An empirical analysis among young people in Moldova and Georgia. In International Empirical Studies on Religion and Socio-Economic Human Rights. Edited by Hans-Georg Ziebertz. Cham: Springer, pp. 129-68. [CrossRef]

van der Tuin, Leo W. J. M., and Clement D. Fumbo. 2012. Women rights and religion among Christian and Islamic students in Tanzania. In Tensions within and between Religions and Human Rights. Edited by Johannes A. van der Ven and Hans-Georg Ziebertz. Leiden: Brill, pp. 203-22. [CrossRef]

van der Ven, Johannes A. 2010. Human Rights or Religious Rules? Leiden: Brill. [CrossRef]

van der Ven, Johannes A. 2013. Towards a legitimate role of religion in the domain of socioeconomic rights: An empirical study among adolescents in North West European countries. In Human Rights and the Impact of Religion. Edited by Johannes A. van der Ven and Hans-Georg Ziebertz. Leiden: Brill, pp. 167-203. [CrossRef] van der Ven, Johannes A. 2016. On the brink of death: Euthanasia from the angle of law, morality and religion: A cross-cultural perspective. In Freedom of Religion in the Twenty-First Century: A Human Rights Perspective on the Relationship between Politics and Religion. Edited by Hans-Georg Ziebertz and Ernst H. Ballin. Leiden: Brill, pp. 257-99. [CrossRef]

van der Ven, Johannes A. 2020. Towards a legitimate role of religion in the domain of socio-economic rights: An empirical study among adolescents in North West European countries. In International Empirical Studies on Religion and Socio-Economic Human Rights. Edited by Hans-Georg Ziebertz. Cham: Springer, pp. 9-38. [CrossRef]

van der Ven, Johannes A., and Hans-Georg Ziebertz, eds. 2012. Tensions within and between Religions and Human Rights. Leiden: Brill. [CrossRef]

van der Ven, Johannes A., and Hans-Georg Ziebertz, eds. 2013. Human Rights and the Impact of Religion. Leiden: Brill.

Vonk, Jennifer, and Jerrica Pitzen. 2016. Religiosity and the formulation of causal attributions. Thinking and Reasoning 22: 119-49. [CrossRef]

Webb, Raymond J., and Fatma J. Asa'd. 2018. Young Palestinian Muslim support for judicial and political human rights. In Political and Judicial Rights through the Prism of Religious Belief. Edited by Carl Sterkens and Hans-Georg Ziebertz. Cham: Springer, pp. 123-44. [CrossRef]

Webb, Raymond J., and Fatma J. Asa'd. 2019. The right to life: A perspective of young Palestinian Muslims. In Euthanasia, Death Penalty and Religion: The Right to Life and Its Limitations: International Empirical Research. Edited by Hans-Georg Ziebertz and Francesco Zaccaria. Cham: Springer, pp. 161-86. [CrossRef]

Webb, Marcia, Sarah A. Chickering, Trina A. Colburn, Dawn Heisler, and Steve Call. 2005. Religiosity and dispositional forgiveness. Review of Religious Research 46: 355-70. [CrossRef] 
Webb, Raymond J., Hans-Georg Ziebertz, Jack Curran, and Marion Reindl. 2012. Human rights among Muslims and Christians in Palestine and Germany. In Tensions within and between Religions and Human Rights. Edited by Johannes A. van der Ven and Hans-Georg Ziebertz. Leiden: Brill, pp. 177-201. [CrossRef]

Webb, Raymond J., Fatma J. Asa'd, and Carl Sterkens. 2020. Young Palestinian Muslim views on socio-economic human rights. In International Empirical Studies on Religion and Socio-Economic Human Rights. Edited by Hans-Georg Ziebertz. Cham: Springer, pp. 169-91. [CrossRef]

Zaccaria, Francesco, Francis-Vincent Anthony, and Carl Sterkens. 2018a. Religion and civil rights in Italy: An empirical exploration among secondary school students. In Religion and Civil Human Rights in Empirical Perspective. Edited by Hans-Georg Ziebertz and Carl Sterkens. Cham: Springer, pp. 91-120. [CrossRef]

Zaccaria, Francesco, Francis-Vincent Anthony, and Carl Sterkens. 2018b. Religion for the political rights of immigrants and refugees? An empirical exploration among Italian students. In Political and Judicial Rights through the Prism of Religious Belief. Edited by Carl Sterkens and Hans-Georg Ziebertz. Cham: Springer, pp. 45-70. [CrossRef]

Zaccaria, Francesco, Francis-Vincent Anthony, and Carl Sterkens. 2019. The impact of religion on attitudes towards abortion and euthanasia: An empirical study among Italian students. In Euthanasia, Death Penalty and Religion: The Right to Life and Its Limitations: International Empirical Research. Edited by Hans-Georg Ziebertz and Francesco Zaccaria. Cham: Springer, pp. 105-38. [CrossRef]

Ziebertz, Hans-Georg. 1993. Religious pluralism and religious education. Journal of Empirical Theology 6: 82-99. [CrossRef]

Ziebertz, Hans-Georg. 1995. Jugendliche in mulitkulturellem und multireligiösem Kontext. SchülerInnen zu Modellen interreligiöser Kommunikation—ein deutsch-niederländischer Vergleich. Religionspädagogische Beiträge 35: 151-67.

Ziebertz, Hans-Georg. 1996. Religion in religious education. Panorama: International Journal of Comparative Religious Education and Values 8: 135-45.

Ziebertz, Hans-Georg. 2003. Religion im Plural. Empirische Befunde zu Einstellungen Jugendlicher. In Glaube in der Welt von Heute. Theologie und Kirche nach dem Zweiten Vatikanischen Konzil. Band 1: Profilierungen. Edited by Thomas Franz and Hanjo Sauer. Würzburg: Echter, pp. 380-414.

Ziebertz, Hans-Georg. 2005. Models of inter-religious learning: An empirical study in Germany. In Religion, Education and Adolescence: International Empirical Perspectives. Edited by Francis Leslie J., Robbins Mandy and Astley Jeff. Cardiff: University of Wales Press, pp. 204-21.

Ziebertz, Hans-Georg. 2007. A move to multi? Empirical research concerning the attitudes of youth toward pluralism and religion's claims of truth. In Interreligious Learning. Edited by Didier Pollefeyt. Leuven: Peters, pp. 3-24.

Ziebertz, Hans-Georg. 2012. The Catholic view of religious pluralism in empirical perspective. In Teaching Religion, Teaching Truth: Theoretical and Empirical Perspectives. Edited by Jeff Astley, Leslie J. Francis, Mandy Robbins and Mualla Selçuk. Bern: Peter Lang, pp. 155-84.

Ziebertz, Hans-Georg. 2019. Human dignity, religious ethics or hedonism: What can predict young people's attitudes in Germany towards the right to life in the cases of euthanasia and abortion? In Euthanasia, Death Penalty and Religion: The Right to Life and Its Limitations: International Empirical Research. Edited by Hans-Georg Ziebertz and Francesco Zaccaria. Cham: Springer, pp. 83-104. [CrossRef]

Ziebertz, Hans-Georg, ed. 2020a. International Empirical Studies on Religion and Socio-Economic Human Rights. Cham: Springer. [CrossRef]

Ziebertz, Hans-Georg. 2020b. Support for women's rights? An empirical study among German youth. In International Empirical Studies on Religion and Socio-Economic Human Rights. Edited by Hans-Georg Ziebertz. Cham: Springer, pp. 235-60. [CrossRef]

Ziebertz, Hans-Georg, and Ernst H. Ballin, eds. 2016. Freedom of Religion in the Twenty-First Century: A Human Rights Perspective on the Relation between Politics and Religion. Leiden: Brill. [CrossRef]

Ziebertz, Hans-Georg, and Gordan Črpić, eds. 2015. Religion and Human Rights. Cham: Springer. [CrossRef]

Ziebertz, Hans-Georg, and Marion Reindl. 2012. Religious socialisation and values as predictors of human rights attitudes: An empirical study among Christian and Muslim Adolescents in Germany. In Tensions within and between Religions and Human Rights. Edited by Johannes A. van der Ven and Hans-Georg Ziebertz. Leiden: Brill, pp. 223-47. [CrossRef] 
Ziebertz, Hans-Georg, and Marion Reindl. 2013. Religion and attitudes towards euthanasia and abortion: An empirical study among young Christians and Muslims in Germany. In Human Rights and the Impact of Religion. Edited by Johannes A. van der Ven and Hans-Georg Ziebertz. Leiden: Brill, pp. 119-43. [CrossRef]

Ziebertz, Hans-Georg, and Carl Sterkens, eds. 2018. Religion and Civil Human Rights in Empirical Perspective. Cham: Springer. [CrossRef]

Ziebertz, Hans-Georg, and Francesco Zaccaria, eds. 2019. Euthanasia, Death Penalty and Religion: The Right to Life and Its Limitations: International Empirical Research. Cham: Springer. [CrossRef]

Ziebertz, Hans-Georg, Susanne Döhnert, and Alexander Unser. 2018. Predictors of attitudes towards human dignity: An empirical analysis among youth in Germany. In Religion and Civil Human Rights in Empirical Perspective. Edited by Hans-Georg Ziebertz and Carl Sterkens. Cham: Springer, pp. 17-60. [CrossRef]

Publisher's Note: MDPI stays neutral with regard to jurisdictional claims in published maps and institutional affiliations.

(C) 2020 by the authors. Licensee MDPI, Basel, Switzerland. This article is an open access article distributed under the terms and conditions of the Creative Commons Attribution (CC BY) license (http://creativecommons.org/licenses/by/4.0/). 